REPORTS OF MORPHOLOGY
$\begin{gathered}\text { Official Journal of the Scientific Society of Anatomists, } \\ \text { Histologists, Embryologists and Topographic Anatomists } \\ \text { of Ukraine } \\ \text { journal homepage: https://morphology-journal.com }\end{gathered}$

\title{
Morphological analysis of interstitial Cajal cells and mast cells in experimental hyperactivity bladder and stress incontinence under influence of pharmacocorrection
}

\section{latsyna O.I.', Vernygorodskyi S.V.' ${ }^{2}$, Kostyev F.I. ${ }^{1}$}

${ }^{1}$ Odessa National Medical University, Ministry of Public Health, Odessa, Ukraine;

${ }^{2}$ Vinnytsia National Pirogov Memorial Medical University, Vinnytsia, Ukraine

\section{ARTICLE INFO}

Received: 9 March, 2018

Accepted: 12 April, 2018

UDC: $616.62 .008 .221 /$

.222:615.015:612.08

\section{CORRESPONDING AUTHOR}

e-mail: vernset@ukr.net

Vernygorodskyi S.V.
The existing data indicate the multifactorial mechanisms of development of the overactive bladder $(O A B)$, but the issue of $O A B$ pathogenesis remains unclear. In more recent times, the neurogenic theory of $O A B$ genesis has being accompanied by the increasing attention to the study of morphological changes that occur in the smooth myocytes of the detrusor and their interaction with the extracellular matrix. Therefore, the objective of our study became the evaluation of distribution of interstitial Cajal cells (ICC) and basophilic granulocytes (BG) in the structural elements of the bladder wall under stress urinary incontinence and its overactivity before and after treatment with Mirabegron, Spasmex, Quercetin and combination thereof with testosterone and estradiol, using histochemical and immunohistochemical methods. The experimental models of $O A B$ and stress urinary incontinence (SUI) presented the increase in the amount and functional activity of $B G$ revealed by histological and immunohistochemical methods, as well as ICC at all terms of OAB monitoring, while the SUI presented with high concentration and functional activity of $B G$ only after 14 days of the experiment. After 28 days, we observed a sharp decrease of the parameters, indicating decompensation and depletion of the functional activity. The number of ICC decreased under SUI after both 14 days and 28 days of the experiment. The group of experimental animals receiving Spasmex and its combination with hormones, presented no significant effect on the quantitative and qualitative composition of BG and ICC at OAB and SUI on Day 14 of the experiment, but the combination with testosterone demonstrated statistically reliable $(p<0.001)$ reduction of $B G$ and ICC expression in the muscle layer of the bladder after 14 days, and unreliable after 28 days of the experiment $(p>0.05)$. The administration of Mirabegron alone and especially its combination with testosterone and estradiol presented positive trends in histochemical and immunohistochemical expression of BG and ICC. The experiment proved high efficacy of Quercetin in combination with testosterone and estradiol under OAB and SUI, confirmed by stabilization of the functional activity of $B G$ and ICC quantitative composition.

Keywords: overactive urinary bladder, stress urinary inconsistency, immunohistochemical evaluation, interstitial Cajal cells, mast cells, pharmacocorrection.

\section{Introduction}

Urinary incontinence (UI) is a disease that affects the quality of life of more than 200 million patients worldwide. The sharp annual increase in the number of reviews on this issue indicates a huge scope of research in this medical problem [18]. Despite the increasing number of scientific papers dedicated to this issue, the mechanisms of urinary incontinence under overactive urinary bladder $(O A B)$ and stress urinary incontinence (SUI) remain unrevealed. We are still unaware of the exact causes of $\mathrm{OAB}$ development, which can reliably lead to formation of a mechanism of urgent and accelerated urination. Most authors tend to associate the emergence of OAB symptoms with ischemia of the bladder-emptying muscle (detrusor) most often caused by infravesical obstruction or arteriolosclerosis. The disturbance of blood supply to the bladder muscle-emptying muscle results in the post- 
synaptic denervation with subsequent structural changes of intercellular junctions in the myocytes. The difference in the physiological characteristics of the detrusor-sphincter apparatus and the ureter gives us the reason to differentiate three smooth muscle functional systems of the lower urinary tract - the bladder muscle-emptying muscle, the muscle system of the urinary bladder trigone, and the ureter [6]. The muscle cover of the bladder is a complex apparatus, consisting of many types of cells: smooth myocytes, nerve cells, and the population of interstitial cells (IC). According to some authors, the spontaneous rhythmic electrical activity is a universal mechanism for regulating the tone of smooth muscle cells (SMC) of visceral organs [3], including the organs of the urinary system.

Just like in the gastrointestinal tract (GIT), IC of the urinary bladder (UB) coordinate the electrical and contractive activity of large SMC populations by synchronizing their individual oscillators. Such synchronization is achieved by combining the activity of individual oscillators into a unified local driver due to a long depolarizing signal that goes through the gap junctions [8]. In UB, they were identified by co-authors as Smet in 1996 [25]. Due to their origin, IC carry a neuronal marker, the receptor tyrosine kinase (cKit) (CD117+) and a marker of cells of mesenchymal origin (vimentin), used to identify these cells in tissues of various organs. IC are spindle- or star-like cells with processes that contact on the one side with neurons (nerve fibers), and with smooth myocytes on the other side [4, 24]. Since the full identity of these cells with GIT and CNS Cajal cells has not been proved yet, the term "interstitial Cajal cell like cells", abbreviated as ICC-LC, or interstitial cells of Cajal (ICC) are used for their differentiation.

According to the results of the study by Vahabi et al. (2011), ICC have a close relationship with cholinergic nerve fibers and play a role of mediator in transmission of cholinergic signals to SMC [26]. The recent data show that ICC can participate not only in transmitting signals between muscle fiber bundles, regulating the bladder-emptying muscle tone, but also in transmitting signals from the afferent nerves to the SMC with involvement of ICC located in the bladder-emptying muscle, and from the urothelia to the afferent nerves with involvement of ICC, located in the suburothelial zone. The disturbance in transmission of these signals may lead to formation of $O A B$ [15].

As for involvement of basophilic granulocytes (BG, granule cells, tissue basophils, mast cells, labrocytes) in the formation of $O A B$ and SUI, most authors point to an increase in their number in the UB wall, but the mechanisms of their involvement in the development of OAB and SUI still remain unclear $[20,27]$. Due to this fact, the role of ICC and $B G$ in formation of urodynamic disorders of the lower urinary tract has been actively studied in recent years.

That is why the objective of this study was to evaluate the immunohistochemical evaluation of distribution of ICC and $B G$ in the structural elements of the bladder wall under stress urinary incontinence and overactivity of the bladder before and after treatment with Mirabegron, Spasmex, Quercetin and combination thereof with testosterone and estradiol.

\section{Material and methods}

The experiments on reproduction of $O A B$ model were conducted on $300 \mathrm{~g}$ sexually mature white laboratory female rats. For this purpose, the animals were divided into two groups. In the first, control group of rats, $0.3 \mathrm{ml}$ sterile physiological solution was injected OD intraperitoneally for 14 days. In order to reproduce the OAB model, animals from the second study group were intraperitoneally administered $0.3 \mathrm{ml}$ OD Homviotensin ${ }^{\circledR}$ (Homviora, Germany) solution containing $0.45 \mathrm{mg}$ of Reserpinum for 14 days. The solution was prepared by grinding tablets in sterile conditions with further dissolving the powder in a physiological solution. We initiated SUI by cutting the pudendal nerve ( $\mathrm{n}$. pudendus). The reproduction of the models was confirmed by histological studies. In the OAB group, Mirabegron $1 \mathrm{ml}$ (Astellas Pharma Europe B.V.) solution was administered OD through the gastric probe from Day 14 for 14 and 28 days ( $8 \mathrm{mg}, 1 / 6$ tablet dissolved in $1 \mathrm{ml}$ of distilled water); 1 ml Kvertin solution (PAT NVTs Borshchahivskyi KhFZ) OD via a gastric probe for 14 and 28 days, containing Quercetin $10 \mathrm{mg}$ (1/4 tablet dissolved in $1 \mathrm{ml}$ of distilled water); Spasmex $1 \mathrm{ml}$ (Dr. R.Pfleger $\mathrm{GmbH}$ ) OD intraperitoneally, containing trospium chloride $0.4 \mathrm{mg}$ (1/4 tablets per $10 \mathrm{ml}$ of physiological saline); Testosterone Propionate solution 0.05 $\mathrm{ml}$ (PAT Farmak) OD for 14 and 28 days intramuscularly, containing $1 \mathrm{mg}$ testosterone, and Divigel (Orion Corporation, Finland) OD for 14 and 28 days by applying gel to shaved portion of the back, which contained $0.2 \mathrm{mg}$ of estradiol; the doses did not change in medicine combinations. In the SUI group, Quercetin and its combination with hormones at the aforementioned doses were used. In total, we used 460 rats, 20 experimental animals in each group.

When working with animal models, we adhered to the requirements of the "Scientific and practical recommendations for keeping and using laboratory animals" issued by the State Pharmacological Center of $\mathrm{MoH}$ of Ukraine (Minutes No.8 dated 22 June 2012).

For histological studies, on days 14 and 28, the animals were withdrawn from the experiment by overdose of $10 \%$ sodium thiopental solution, followed by removal of the bladder and fixing it in a $10 \%$ neutral formalin solution for 24 hours, dehydration in alcohol solutions of growing concentration, clarification in chloroform and sealing in paraffin. 5-7 micron sections were stained with hematoxylin and eosin, and by van Gieson's picrofuchsin and Weigert's resorcin-fuchsin methods [1]; for visualization of $B G$, we used the basic brown.

The immunohistochemistry assay was performed using DAKO and ThermoFisher Scientific paraffin blocks and reagents with monoclonal antibodies CD 117 (c-kit) for identification of ICC by EnVisionTMFLEX and Invitrogen 
Histostain $®-S P$ visualization systems. The immunohistochemical response was evaluated in 10 view fields at 200 and 400x magnification. The expression intensity was evaluated by a semi-quantitative method based on the expressiveness and integrity of basal membrane coloration, the nuclear and cytoplasmic staining of cells according to the following scheme: low, moderate and high, taking into account localization of pathological changes and percentage of positively stained cells by phase analysis using Quick PHOTO MICRO 2.3 computer program. The density of BG and ICC was determined using an optical microscope with magnification of $x 400$. The cells were counted and typed in 10 fields with subsequent recount per unit area ( $S=$ $0.01 \mathrm{~mm}^{2}$ ). The functional activity of BG (degranulation) was evaluated as the ratio of the number of completely degranulated cells to the total number of analyzed cells, expressed as a percentage [2].

The Microsoft Office Excel 2007 program was used for statistical processing of the data. The differences were considered statistically significant at $p<0.05$. UB sites taken from animals before treatment were used as control. The histological preparations were microscoped and photographed using OLIMPUS BX 41 optical microscope at 40, 100, 200 and 400x magnification.

\section{Results}

The experimental animals in the control group had UB lining formed by the transitional epithelium (TE), which consisted of 5-8 layers in a relaxed and 3-4 layers in the contracted state of UB. TE was represented by surface, intermediate and basal cells. The surface cells were large, light, with a free dome-like surface, often containing two nuclei with large nucleoli. The intermediate cells were of polygonal shape, while the basal were of cubic or low-cylindrical shape. TE was placed on its own mucous membrane plate, which separated TE and muscle cover, with collagen fibers dominated in the latter and few isolated elastic fibers.

Its deepest layer consisted of a more loose tissue and contained more elastic fibers, which was typical for submucosal UB base. Collagen and elastin were the two main proteins we registered, which were part of the extracellular matrix $(E C M)$ of the connective tissue. Collagen is known to be responsible for breaking strength and integrity, while elastin endures elasticity and tensity of tissues.

Due to the fact that BG is also positively stained with $C D$ 117 , the cuts were pre-treated with the basic brown to determine BG localization for ICC identification. Cells with rounded nuclei and cytoplasm with granular inclusions were recorded as BG, while cells with positively stained spindleshaped nuclei and cytoplasm were defined as ICC.

The histochemical study of UB wall in the control group using the basic brown revealed BG located predominantly around the vascular walls, both in the submucosal and in muscular and serous membranes (Fig. 1).

In this case, in most of them, the cytoplasmic membrane preserved a moderate, sometimes weak functional activity,

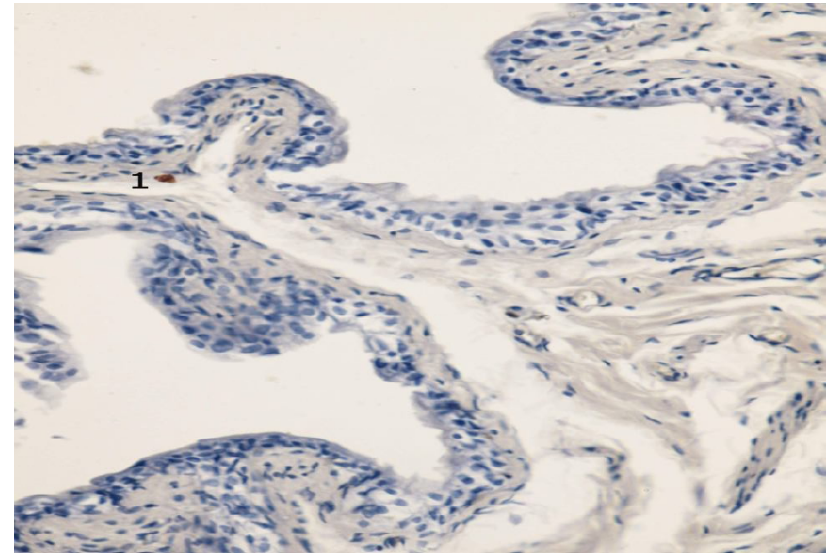

Fig. 1. Isolated basophilic granulocytes with weak functional activity in the submucosal wall of the bladder. Day 14, control group. Basic brown. x200. 1 - basophil granulocyte.

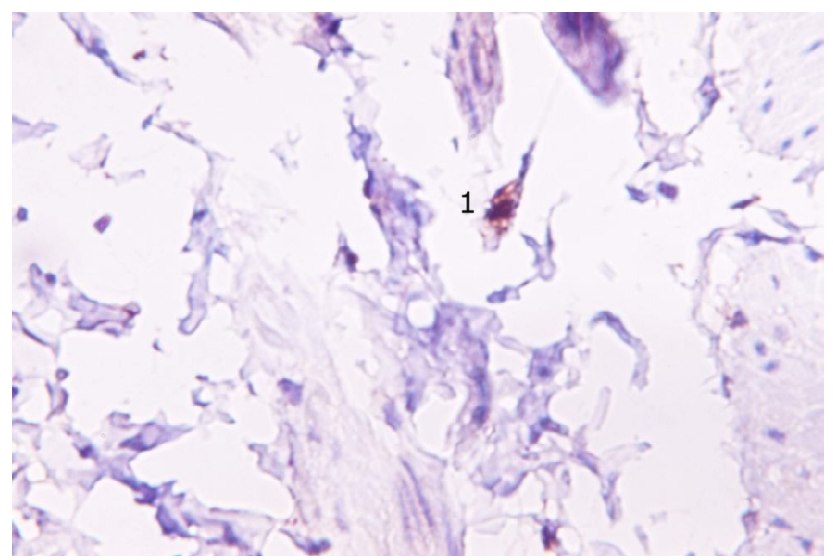

Fig. 2. Interstitial cell of Cajal with characteristic processes between smooth muscle bladder myocytes. 14 Day, control group. Immunohistochemical marking CD 117, x1000. 1 - interstitial cell of Cajal.

which was characterized by the ratio of degranulated cells to all BG (percent). The morphometric analysis revealed an average of $3.200 \pm 0.489 \mathrm{BG}$ per $0.01 \mathrm{~mm}^{2}$, of which $10.00 \pm 4.08 \%$ were functionally active (Table 1 ).

The immunohistochemical study of the ICC of UB wall in animals of the control group revealed that ICC were mainly localized in the suburothelial layer, in the own plate of the mucous membrane, along the longitudinal bundles of detrusor SMC and between them, and less frequently in the subserous sections, predominantly in the bottom and neck of the bladder. It was possible to differentiate the cells with typical processes (processed) and those resembled fibroblasts (fibroblast-like) by the structure. It's worthy to note that processed ICC (Fig. 2) were more common in SMC, fibroblast-like cells, in subepithelial and subserous sections of UB wall.

Morphological characteristics of the bladder-emptying muscle under experimental overactive urinary bladder. The group of rats with OAB administered Homviotensin for 2 weeks was characterized by an increase in the number of BG and ICC (Tables 1, 2, Fig. 3, 4) with a definite prevalence in the neck section (UB transition to the ureter), associated 
Morphological analysis of interstitial Cajal cells and mast cells in experimental hyperactivity bladder and stress...

Table 1. Quantitative composition of basophilic granulocytes and their functional activity in \% in the bladder wall under disorders of urodynamics of the lower urinary tract on Days 14 and 28 of the experiment, calculated as for $0.01 \mathrm{~mm}^{2}$ surface.

\begin{tabular}{|c|c|c|c|c|c|}
\hline \multicolumn{2}{|c|}{ Animal group \ Pharmacocorrection type } & \multicolumn{2}{|c|}{$\begin{array}{l}\text { Basophilic granulocytes, } \\
\text { count }\end{array}$} & \multicolumn{2}{|c|}{$\begin{array}{l}\text { Basophilic granulocytes, functional } \\
\text { activity }\end{array}$} \\
\hline & & Day 14 & Day 28 & Day 14 & Day 28 \\
\hline \multicolumn{2}{|r|}{ Control group } & $3.200 \pm 0.489$ & $4.000 \pm 0.365$ & $10.00 \pm 4.08$ & $8.500 \pm 1.979$ \\
\hline \multicolumn{2}{|r|}{ OAB } & $18.60 \pm 0.84^{\dagger}$ & $15.90 \pm 0.71$ & $42.00 \pm 5.12^{\dagger}$ & $38.00 \pm 5.12^{\dagger}$ \\
\hline \multicolumn{2}{|r|}{ sul } & $7.600 \pm 0.426^{\dagger}$ & $2.000 \pm 0.381^{\dagger}$ & $27.00 \pm 3.67^{\dagger}$ & $3.630 \pm 1.363^{\dagger}$ \\
\hline \multirow{15}{*}{$\begin{array}{c}\text { OAB } \\
\text { pharmacocorrection }\end{array}$} & Mirabegron & $15.30 \pm 0.39^{*}$ & $13.90 \pm 0.69^{*}$ & $30.00 \pm 2.69^{*}$ & $26.50 \pm 5.73^{*}$ \\
\hline & Spasmex & $17.80 \pm 0.63^{\#}$ & $15.60 \pm 0.56^{\#}$ & $39.00 \pm 5.26^{*}$ & $36.00 \pm 3.40$ \\
\hline & Quercetin & $15.80 \pm 0.78^{*}$ & $11.50 \pm 0.82^{*}$ & $29.50 \pm 2.93^{*}$ & $20.50 \pm 5.04^{*}$ \\
\hline & Mirabegron+Testosterone & $13.00 \pm 0.74^{*}$ & $10.80 \pm 0.42^{*}$ & $28.50 \pm 2.24^{*}$ & $23.00 \pm 3.59^{*}$ \\
\hline & Mirabegron+Estradiol & $13.70 \pm 0.45^{*}$ & $10.90 \pm 0.48^{*}$ & $29.00 \pm 2.67^{*}$ & $25.50 \pm 2.93^{*}$ \\
\hline & Mirabegron+Testosterone+Estradiol & $12.80 \pm 0.51^{*}$ & $9.500 \pm 0.619^{*}$ & $27.50 \pm 2.39^{*}$ & $21.50 \pm 3.17^{*}$ \\
\hline & Spasmex+Testosterone & $15.70 \pm 0.66^{\circ}$ & $14.80 \pm 0.49^{\#}$ & $36.50 \pm 4.08^{\#}$ & $32.00 \pm 4.16^{\#}$ \\
\hline & Spasmex+Estradiol & $16.00 \pm 0.60^{\circ}$ & $14.90 \pm 0.60^{\#}$ & $37.50 \pm 4.73^{\#}$ & $34.00 \pm 3.23^{\#}$ \\
\hline & Spasmex+ Testosterone+Estradiol & $15.10 \pm 0.67^{\circ}$ & $14.10 \pm 0.50^{\#}$ & $33.50 \pm 3.65^{\#}$ & $30.00 \pm 3.65^{\#}$ \\
\hline & Quercetin+Testosterone & $13.90 \pm 0.64^{*}$ & $10.40 \pm 0.58^{*}$ & $26.50 \pm 2.89^{*}$ & $17.00 \pm 4.23^{*}$ \\
\hline & Quercetin+ Estradiol & $14.30 \pm 0.39^{*}$ & $10.60 \pm 0.67^{*}$ & $28.50 \pm 1.50^{*}$ & $20.50 \pm 3.61^{*}$ \\
\hline & Quercetin+ Testosterone+Estradiol & $13.30 \pm 0.58^{*}$ & $8.30 \pm 0.39^{*}$ & $26.00 \pm 3.64^{*}$ & $12.00 \pm 3.26^{*}$ \\
\hline & Testosterone & $15.10 \pm 0.41^{*}$ & $11.00 \pm 0.49^{*}$ & $29.50 \pm 2.52^{*}$ & $27.50 \pm 4.17^{*}$ \\
\hline & Estradiol & $15.60 \pm 0.50^{*}$ & $11.20 \pm 0.39^{*}$ & $33.00 \pm 2.00^{*}$ & $28.00 \pm 4.90^{*}$ \\
\hline & Testosterone+Estradiol & $14.10 \pm 0.52^{*}$ & $9.600 \pm 0.476^{*}$ & $27.00 \pm 2.49^{*}$ & $22.00 \pm 4.16^{*}$ \\
\hline \multirow{5}{*}{$\begin{array}{c}\text { SUI } \\
\text { pharmacocorrection }\end{array}$} & Quercetin & $5.900 \pm 0.378^{8}$ & $5.400 \pm 0.400$ & $17.50 \pm 2.14$ & $11.50 \pm 2.99$ \\
\hline & Testosterone & $5.700 \pm 0.472^{\&}$ & $5.200 \pm 0.359^{\&}$ & $18.00 \pm 1.85^{\&}$ & $13.00 \pm 3.35^{8}$ \\
\hline & Estradiol & $6.000 \pm 0.494^{\&}$ & $5.600 \pm 0.426^{8}$ & $19.0 \pm 2.67^{\&}$ & $15.00 \pm 3.16^{8}$ \\
\hline & Testosterone+Estradiol & $5.600 \pm 0.339^{\&}$ & $5.500 \pm 0.401^{\&}$ & $16.50 \pm 2.36^{8}$ & $11.00 \pm 3.78^{8}$ \\
\hline & Quercetin+Testosterone+ Estradiol & $5.300 \pm 0.495^{\&}$ & $4.400 \pm 0.476^{8}$ & $16.00 \pm 2.21^{8}$ & $10.00 \pm 2.98^{\&}$ \\
\hline
\end{tabular}

Note: OAB - overactive bladder, SUI - stress urinary incontinence, ICC - interstitial cells of Cajal; ${ }^{*}-p<0.001$ compared to OAB; ${ }^{\dagger}-p<0.001$ compared to control; \& $-p<0.001$ compared to SUI; ${ }^{\circ}-p<0.05$ compared to OAB; $\#$ - $p>0.05$ compared to OAB.

with hypertrophic and degenerative changes in smooth myocytes and the interstitium swelling phenomena. We observed SMC polymorphism, varied in size, degree of staining and size of nuclei. The cells had a different saturation with contractile proteins and looked either darker or lighter; most of smooth myocytes were hypertrophied.

The vessels of the microcirculatory stream were dilated, some of them with a thinned wall, dystrophic changes in the endothelium, and erythrocytic stasis, other with thickened walls due to edema, hyperplasia, hypertrophy of collagen fibrils, dilated perivascular space and accumulation of BG in it.

As Table 1 shows, the average number of cells in the degranulation state was $42.00 \pm 5.12 \%$ and statistically significantly $(p<0.001)$ greater compared to the control group $(10.00 \pm 4.08 \%)$. In the event of degranulation, BG granules that came out to the extracellular space, acquired a variety of optical densities, lost their content, the BG cytoplasm illuminated, with some of them becoming hollow. The granules were of different sizes and vacuolized.
Polymorphism and different size of BG and their granules reflect the processes of cellular degranulation. The predominantly vascular location of BG creates conditions when degranulation products are located in the wall of microvessels, leading to stasis and contributing to ischemia and hypoxia of the bladder-emptying muscle, the important components of OAB pathogenesis.

In a group of experimental animals that received Spasmex separately from hormonal preparations at a morphological analysis on Day 14 of the study, hypertrophic and dystrophic changes in muscle fibers with minor areas of their vacuolization and disorganization were detected, the number of BG and ICC decreased somewhat, but this decrease was not statistically reliable ( $p>0.05$, Table 1,2$)$.

However, combinations of Spasmex with testosterone, estradiol, and especially combinations of these medicines at this phase of the study, presented with a significant decrease in the amount of BG, despite keeping their functional activity at high level (Table 1). As for ICC, 
Table 2. Quantitative composition of ICC in the bladder wall under disorders of urodynamics of the lower urinary tract on Days 14 and 28 of the experiment, calculated as for $0.01 \mathrm{~mm}^{2}$ surface.

\begin{tabular}{|c|c|c|c|}
\hline \multirow{2}{*}{\multicolumn{2}{|c|}{ Animal group \ Pharmacocorrection type }} & \multicolumn{2}{|c|}{ Interstitial cells of Cajal } \\
\hline & & Day 14 & Day 28 \\
\hline \multicolumn{2}{|r|}{ Control group } & $5.700 \pm 0.422$ & $5.000 \pm 0.421$ \\
\hline \multicolumn{2}{|r|}{ OAB } & $18.10 \pm 0.52^{\dagger}$ & $16.60 \pm 0.63^{\dagger}$ \\
\hline \multicolumn{2}{|r|}{ sul } & $2.200 \pm 0.416^{\dagger}$ & $1.900 \pm 0.284^{\dagger}$ \\
\hline \multirow{15}{*}{ OAB pharmacocorrection } & Mirabegron & $14.80 \pm 0.42^{*}$ & $13.90 \pm 0.69^{*}$ \\
\hline & Spasmex & $17.90 \pm 0.57^{\#}$ & $15.60 \pm 0.56^{\#}$ \\
\hline & Quercetin & $15.40 \pm 0.63^{*}$ & $11.50 \pm 0.82^{*}$ \\
\hline & Mirabegron+Testosterone & $12.50 \pm 0.58^{*}$ & $10.80 \pm 0.42^{*}$ \\
\hline & Mirabegron+Estradiol & $12.90 \pm 0.58^{*}$ & $10.90 \pm 0.48^{*}$ \\
\hline & Mirabegron+Testosterone+Estradiol & $12.20 \pm 0.51^{*}$ & $9.500 \pm 0.619^{*}$ \\
\hline & Spasmex+Testosterone & $16.40 \pm 0.50^{*}$ & $14.80 \pm 0.49^{*}$ \\
\hline & Spasmex+Estradiol & $16.50 \pm 0.60^{\#}$ & $14.90 \pm 0.60^{\#}$ \\
\hline & Spasmex+ Testosterone+Estradiol & $16.10 \pm 0.66^{*}$ & $14.10 \pm 0.50^{*}$ \\
\hline & Quercetin+Testosterone & $13.10 \pm 0.67^{*}$ & $10.40 \pm 0.58^{*}$ \\
\hline & Quercetin+ Estradiol & $13.50 \pm 0.60^{*}$ & $10.60 \pm 0.67^{*}$ \\
\hline & Quercetin+ Testosterone+Estradiol & $12.40 \pm 0.70^{*}$ & $8.300 \pm 0.395^{*}$ \\
\hline & Testosterone & $14.80 \pm 0.39^{*}$ & $11.00 \pm 0.49^{*}$ \\
\hline & Estradiol & $14.90 \pm 0.64^{*}$ & $10.90 \pm 0.43^{*}$ \\
\hline & Testosterone+Estradiol & $13.80 \pm 0.55^{*}$ & $9.600 \pm 0.476^{*}$ \\
\hline \multirow{5}{*}{ SUI pharmacocorrection } & Quercetin & $4.100 \pm 0.276^{\&}$ & $4.100 \pm 0.316^{8}$ \\
\hline & Testosterone & $3.600 \pm 0.426^{8}$ & $3.900 \pm 0.423^{8}$ \\
\hline & Estradiol & $3.500 \pm 0.268^{\&}$ & $3.800 \pm 0.359^{\&}$ \\
\hline & Testosterone+Estradiol & $4.000 \pm 0.516^{8}$ & $4.200 \pm 0.290^{8}$ \\
\hline & Quercetin+Testosterone+ Estradiol & $4.300 \pm 0.334^{\&}$ & $4.700 \pm 0.300^{8}$ \\
\hline
\end{tabular}

Note: OAB - overactive bladder, SUI - stress urinary incontinence, ICC - interstitial cells of Cajal; ${ }^{*}-p<0.001$ compared to OAB; ${ }^{\dagger}-p<0.001$ compared to control; \& $-p<0.001$ compared to SUI; \# - p>0.05 compared to OAB.

combination of Spasmex with estradiol demonstrated statistically unreliable ICC reduction $(p<0.05$, Table 2$)$ after 14 days of the study.

In the groups of rats administered Mirabegron and Quercetin and combinations thereof with hormonal preparations after 14 days, a reduction in hypertrophic and dystrophic changes in smooth myocytes was observed. The amount of BG and their functional activity was statistically significantly $(p<0.001)$ lowered compared to the one in the OAB group; the same changes were observed under the morphometric analysis of ICC (Tables 1, 2).

Testosterone and estradiol administered alone and combinations thereof demonstrated a decrease in the amount of BG and ICC; however the positive effect of hormonal medicines was lower than the accumulated effect thereof on BG and ICC compared to Mirabegron and Quercetin.

After 28 days of Homviotensin administration, the experimental animals from $O A B$ group demonstrated progressive dystrophic changes in smooth myocytes represented by fibrosis of UB wall muscular layer with patches of sclerosis as a growth of connective tissue between the UB wall smooth muscle fibers and their replacement by fibrous ones. The number of BG and ICC in the degranulation state somewhat decreased compared with the previous period (Table 1, 2), which may be associated with decompensation (depletion) of their functional activity.

The experimental animals administered Mirabegron and its combination with testosterone and estradiol showed a statistically significant $(p<0.001)$ decrease in both BG with their functional activity and ICC (Table 1, 2).

After 28 days of the experiment, no significant changes were recorded in the group of Spasmex and its combination with hormonal medicines in the quantitative composition and functional activity of BG compared to OAB $(p>0.05)$. The number of ICC decreased statistically significantly when administered a combination with testosterone and the combination of testosterone and estradiol with Spasmex $(p<0.05)$. However, the results in Spasmex+Estradiol group were not statistically reliable for ICC count $(p>0.05)$.

Separate administration of testosterone, estradiol and 


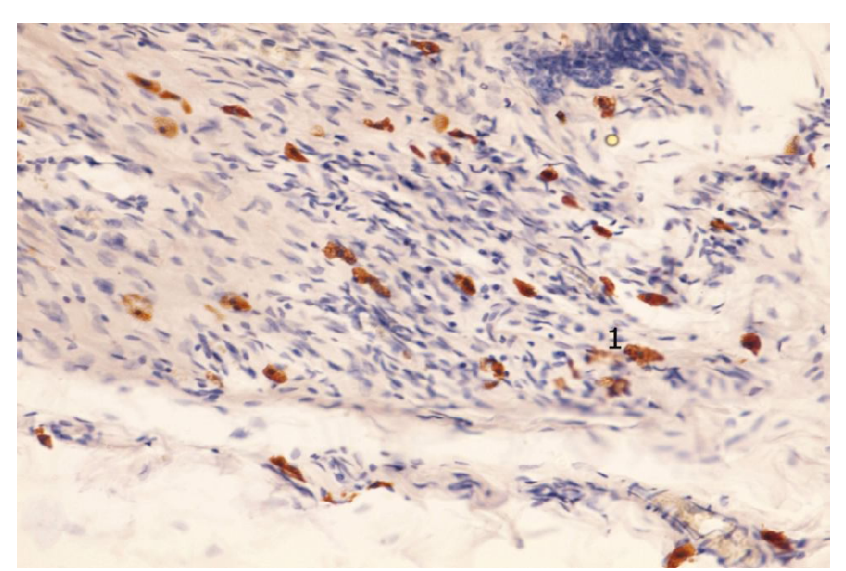

Fig. 3. The increase in the number of basophilic granulocytes with high functional activity in subserous parts of bladder wall. Day 14 , OAB. Basic brown, x200. 1 - basophilic granulocytes.

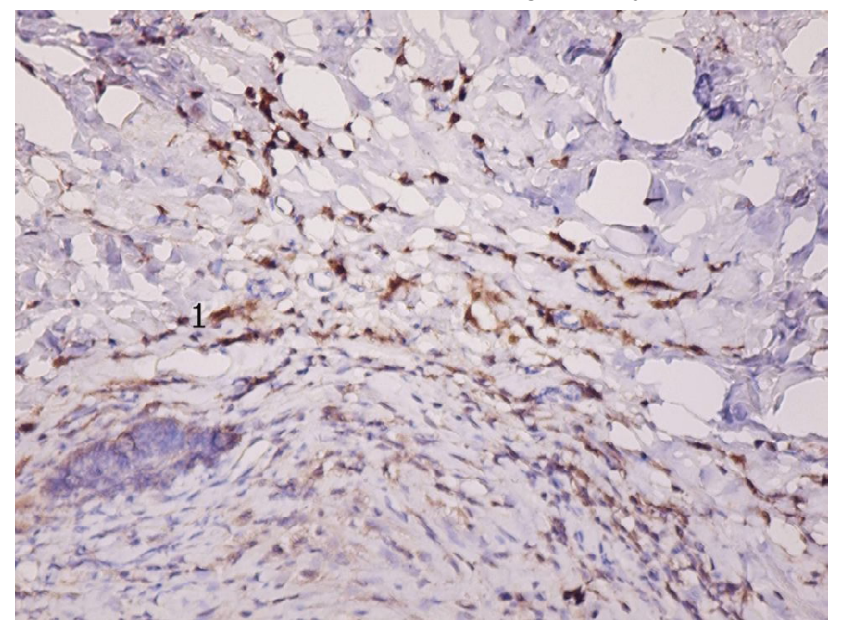

Fig. 4. The increase in the number of interstitial cells of Cajal between the muscle fibers of bladder wall. Day 14, OAB. Immunohistochemical marking CD 117, x400. 1 - interstitial cells of Cajal.

combinations thereof statistically significantly reduced BG count, their functional activity and ICC count $(p<0.001)$, but the efficacy was inferior compared to Quercetin in combination with hormonal medicines (Tables 1, 2).

As for ICC quantitative changes in this monitoring period, the best results were obtained for Quercetin in combination with estradiol and testosterone $-8.300 \pm 0.395, p<0.001$ (Table 2).

Morphological characteristic of the bladder-emptying muscle under experimental stress urine incontinence after ligation of $n$. pudendus.

The morphological examination of the bladder wall in experimental animals with ligated $n$. pudendus presented with the opposite results compared with OAB group. After 14 days, mostly atrophic changes in the bladder wall were observed, which were manifested by a significant thinning of the muscular layer. As we can see from Table 1, the BG count $(7.600 \pm 0.426)$ and the level of their functional activity $(27.00 \pm 3.67 \%)$ were significantly increasing $(p<0.001)$ compared with the control group of rats $-3.200 \pm 0.489$ and $10.00 \pm 4.08$, respectively.
The ICC count, on the contrary, decreased $(2.200 \pm 0.416$, $\mathrm{p}<0.001$ ) by almost twice compared with the control group at this phase of the study $-5.700 \pm 0.422$ (Table 2).

Pharmacorrection of SUI using Quercetin, testosterone, estradiol and combinations thereof resulted in a decrease in the amount and functional activity of both BG and ICC on Day 14 of the study (Table 2).

On Day 28 of the experiment, we observed the progression of dystrophic and sclerotic changes in smooth myocytes, blood vessel walls and submucosal UB base in SUI group after ligation of $n$. pudendus. The BG count $(2.000 \pm 0.381)$ and their functional activity $(3.630 \pm 1.363 \%)$ decreased sharply $(p<0.001)$ compared to the control group of rats $-4.000 \pm 0.365$ and $8.500 \pm 1.979 \%$, respectively.

Quantitative ICC changes after ligation of $n$. pudendus in SUI rats deteriorated at this phase of the study $(1.900 \pm 0.284)$ versus $5.000 \pm 0.421$ in the control group $(p<0.001)$.

Correction of SUI with Quercetin, testosterone, estradiol and combinations thereof stabilized the quantitative composition and functional activity of BG and ICC and their morphometric parameters approached the ones in the control group (Tables 1, 2).

Consequently, the results of the morphological analysis of $B G$ and ICC in OAB model were characterized by an increase in the amount and functional activity of BG as well as ICC at all phases of the study, while in SUI model the amount and functional activity of BG were high only after 14 days of the experiment, which could be explained by compensatory response to reduction of the total volume of nerve elements in the wall of the bladder caused by atrophy and fibrotic changes in the UB wall. After 28 days, we observed a sharp decrease of the volume, indicating decompensation and depletion of their functional activity. The ICC count decreased under SUI after both Day 14 and Day 28 of the experiment.

The administration of Spasmex alone did not statistically significantly influence the functional activity and quantitative composition of $B G$ s under $O A B$, but its combinations with hormonal medicines and combinations of testosterone and estradiol demonstrated positive changes only after 14 days of the experiment, whilst the decrease in BG count and their functional activity were not statistically reliable $(p<0.05)$ on Day 28 .

The pharmacokinetic correction with Mirabegron, Quercetin and combinations thereof with testosterone, estradiol and combination of the latter, as well as the separate administration of hormonal medicines presented with a positive effect, but the best results were obtained with the combination of Quercetin with testosterone and estradiol at all phases of the study in both OAB and SUI groups.

\section{Discussion}

The results of our study established that experimental animals with $O A B$ had increased rhythmic activity of the bladder-emptying muscle, associated with an increase in the number of c-kit-positive cells (ICC) at all phases of the 
study, which coincides with the findings of other authors [16, 17]. The high level of $B G$ degranulation along with an increase in their count in $O A B$ group indicates an increase in their functional activity under $O A B$. The analysis of literature and our data suggest that $B G$ products influence on the contractility and relaxation of UB smooth muscle. As for BG, the ability to influence the muscles of the detrusor and the nervous elements is quite large and preconditioned by production of various substances by these cells: biogenic amines (histamine, serotonin, dopamine), proteoglycans, neutral peptidases (chymase, tryptase), acid hydrolase, leukotrienes, prostaglandins, platelet activation factors, some cytokines (IL-3, IL-4, IL-5, IL-6, IL-10, and IL-13), fibroblast growth factor (FGF), stem cell factor (GM-CSF), vascular permeability and vessel endothelium growth factor [9, 22, 27]. In addition to production of a large group of cytokines, the synthesis of FGF indicates the involvement of these cells in the sclerotic changes in UB wall; the fact established in our work, which is in agreement with the data of other researchers [22]. Unlike other studies, in our experiment we practically did not observe inflammatory infiltration (white blood cells, lymphocytes, macrophages) of UB wall, noted by other authors [20]. In some animals (2\%), we observed only isolated lymphocytes that went beyond the boundaries of the vascular walls in the interstitium, which offset the role of these cells as pathogenetic links in the development of OAB and SUI. In our opinion, the contractile activity of UB SMC is brought into effect largely due to the hypoxic state of structural elements of the wall, as evidenced by the numerous stasis in vessels of the microcirculatory stream.

The morphological analysis of smooth myocytes under $O A B$ and SUI confirms the effect of BG and ICC on the contraction state of SMC, as in OAB and SUI models, we observed a polymorphism of smooth myocytes by size, degree of staining and size of the nuclei. The cells had different saturation with contractile proteins and looked either darker or lighter; part of smooth myocytes was hypertrophied or atrophied. Our data on SMC morphological changes coincide with the previous studies [17].

According to our study, the animals in Mirabegron group and combinations thereof with hormonal medicines presented with a significant decrease in the functional BG activity, which may indicate the presence of a stabilizing effect on BG cell membranes in Mirabegron in addition to the stimulating effect on beta3-adrenergic receptors.

The effect of hormonal preparations administered alone on ICC quantitative composition is explained by the presence of receptors in ICC nuclei that are sensitive to both androgens and estrogens, which has also been shown in the studies by other authors [11].

According to McHale et al. (2006) and Hashitani H., Lang R.J. (2010), the cyclic discharge of $\mathrm{Ca} 2+$ from intracellular depot of ICC causes opening Ca-activating Cl-channels, which leads to depolarization of the cytoplasmic membrane spreading to surrounding smooth myocytes, which are closely bound with ICC by electric signal $[13,19]$. Placed in different locations, ICC generate the potential not simultaneously, resulting in asynchronous contractions of individual SMC groups. Possible involvement of ICC in the pathogenesis of UB overactivity was confirmed by Okada et al. (2011). He showed that chemical cystitis model rats (intravenous administration of cyclophosphamide or protamine sulfate) presented with statistically significantly more pronounced increase in the frequency of spontaneous UB contractions in the WsRC+/+ rats, as UB of the latter contained c-kit-positive cells and were characteristic of the expression of kit-protein, absent in WsRCWs-/Ws- rats [21]. In our previous studies, we found that paxillin, the selective blocker of calcium-sensitive potassium channels of high conductivity (BKCa), inhibited the potassium streams by about twice, which confirmed the significant role of these channels in regulation of activity of the bladder and their possible involvement in the development of pathology, whereas the liposomal Quercetin increased the inhibited potassium channel [10]. One of the mechanisms for restoring potassium channels in administration of Quercetin may be an increased endothelial NO-synthase expression (eNOS) followed by activation of protein kinase G, which leads to a decrease in $\mathrm{Ca} 2+$ by inhibition of phospholipase $C$ and formation of inositol 1,4,5-triphosphate. These transmitters also stimulate relaxation by activating potassium channels ( $\mathrm{K}+$ channels), which coincides with the data of other authors, for example, hydrogen sulfide activates protein kinase $G$, which results in relaxation of muscle fibers by activating ATP-dependent $\mathrm{K}+$ channels [12]. The relaxing effect of NO-synthase is closely related to activation of soluble guanylate cyclase and accumulation of cyclic guanosine monophosphate (cGMP). The increased concentration of GMP activates cGMP-dependent protein kinase and ATPase involved in dephosphorylation of light myosin chains, which leads to the release of calcium from muscle cells and, as a result, to vasodilation [5]. It should be noted that in addition to the effect on calcium and potassium channels, in our previous studies we also obtained an antioxidant effect both at separate administration of Quercetin and Mirabegron and in combination thereof with hormones, especially with testosterone, associated with an increase in the synthesis of endothelial fraction of NO-synthase [14].

Therefore, the consideration of complex pathogenetic links in interaction of ICC and BG with smooth myocytes, hormonal and metabolic factors in disorders of urodynamics of the lower urinary tract would allow in the future to use this combination of medicines for treatment of OAB and SUI.

Given the leading role of ICC in regulating the contractile activity of smooth myocytes under $A B$ and $S U I$, further study of ICC distribution and functional activity of $B G$ in the structural elements of the bladder wall opens the prospects for changing existing perceptions about the mechanism of urodynamic disorders of the lower urinary tract and development of new medicines for correction and optimizing the therapeutic regimens. 


\section{Conclusion}

1. BG histochemical studies and immunohistochemical analysis of ICC expression in OAB and SUI models confirm their involvement in the pathogenetic mechanisms of urodynamic disorders of the lower urinary tract. According to our research, ICC play the prominent role in the contractile activity of smooth myocytes.

2. The main reaction of $B G$ in modelled $O A B$ was an increase in their count in 14 days and a slight decrease in 28 days of the experiment followed by degranulation, while the models with ligated nerve presented mostly with their degranulation and a significant decrease in the count after 28 days of SUI $(p<0.001)$.

3. In a group of experimental animals receiving Spasmex and its combination with hormones, there was no reliable evidence of their effect on the quantitative and qualitative composition of BG and ICC under OAB and SUI

\section{References}

[1] Artashyan, O. S., Yushkov, B. G., \& Mukhlynin, E. A. (2006). A study of mast cell functional activity at immobilization stress. Cytology, 8, 665-668.

[2] Avtandilov, G. G. (2007). Fundamentals of pathoanatomical practice. Manual (third edition amended). M.: Russian Medical Academy of Postgraduate Education. ISBN 5-7249-0286-9.

[3] Bradding, P., \& Pejler, G. (2018). The controversial role of mast cells in fibrosis. Immunological Reviews, 282(1), 198-231. doi:10.1111/imr. 12626

[4] Bursian, A. V. (2008). Pacemakrs of visceral systems. Usp. Phiziol. Nauk, 4, 3-13.

[5] Chintamaneni, M., Changela, I., Poonia, M., \& Kaur, G. (2010). New insights into molecular targets for urinary incontinence. Indian Journal of Pharmacology, 42(5), 261. doi:10.4103/02537613.69980.

[6] Cretoiu, D., Sanda, M., Popescu, L.M, Ceafalan, L., \& Ardeleanu, C. (2006). Interstitial Cajal-like cells (ICLC) as steroid hormone sensors in human myometrium: immunocytochemical approch. J. Cell. Mol. Med.,10(3), 789-795. doi: 10.1111/j.15824934.2006.tb00438.x

[7] Fernandes, V. S., Ribeiro, A. S. F., Barahona, M. V., Orensanz, L. M., Martinez-Saenz, A., Recio, P.... Hernandez, M. (2013). Hydrogen sulfide mediated inhibitory neurotransmission to the pig bladder neck: Role of KATP channels, sensory nerves and calcium signaling. The Journal of Urology, 190(2), 746756. doi: 10.1016/j.juro.2013.02.103.

[8] Hashitani, H., \& Lang, R. J. (2010). Functions of ICC-like cells in the urinary tract and male genital organs. Journal of Cellular and Molecular Medicine, 14(6a), 1199-1211. doi:10.1111/ j.1582-4934.2010.01043.x.

[9] latsyna, O., Melnyk M., Parshikov, A., Kostev, F., Furmanov, Yu., \& Soloviev, A. (2016). Liposomal quercetin normalizes potassium conductivity in isolated smooth muscle cells of rat's overactive bladder. Pharmacology and medical toxicology, 6(51), 83-88.

[10] latsyna, O. I., Vernygorodskyi, S. V., \& Kostyev, F. I. (2018). Morphological assessment of NO-synthase distribution in overactive bladder and stress urine incontinence in animal models administered with experimental pharmacocorrection regimens. Georgian medical news, 279, 143-150.

[11] Kirpatovskiy, V. I., Frolova, E. V., \& Nadtochiy O. N. (2013). on Day 14 of the experiment, but a significantly $(p<0.001)$ decreased expression of BG and ICC in the UB muscle layer after 14 days was observed in combination with testosterone, unreliable after 28 days ( $p>0.05)$.

4. Administration of Mirabegron alone and especially its combination with testosterone and estradiol demonstrated positive trends in histochemical and immunohistochemical expression of BG and ICC. Stabilization of functional activity of BG was characterized by a decrease in the number of degranulated and vacuolized cells.

5. The results of the study proved the positive effect of Quercetin for treatment of experimental $\mathrm{OAB}$ and $\mathrm{CMC}$, and its high efficacy in combination with testosterone and estradiol, which was confirmed by stabilization of the functional activity of BG and ICC quantitative composition at all monitoring phases.

Spontaneous rhythmic activity of the urinary system: the role of interstitial cells, the biological significance, pathophysiological aspects (literature review). Experimental and clinical urology, 4, 70-77.

[12] Krylova, O. O. (2011). The role of NO in the development of chronic pancreatitis. Buk. Med. Herald, 15(2), 218-221.

[13] Kubota, Y., Kojima, Y., Shibata, Y., Imura, M., Sasaki, S., \& Kohri, K. (2011). Role of KIT-Positive interstitial iells of Cajal in the urinary bladder and possible therapeutic target for overactive bladder. Advances in Urology, 2011, 1-7. doi:10.1155/2011/816342.

[14] Kuzgunbay, B., Doran, F., Bayazit, Y., Turunc, T., Satar, N., \& Kayis, A. A. (2009). The effects of ureteral obstruction on Cajal-like cells in rats. Journal of Pediatric Urology, 5(4), 269273. doi:10.1016/j.jpurol.2008.12.006.

[15] Lagou, M., Drake, M.J., Markerink-van Ittersum, M., De Vente, J., \& Gillespie, J.I. (2006). Interstitial cells and phasic activity in the isolated mouse bladder. BJU International, 98(3), 643650. doi:10.1111/j.1464-410x.2006.06255.x.

[16] Li, M., Yang, K., Wang, X., Xu, X., Zhu, L., \& Wang, H. (2015). Mast cells infiltration and decreased E-cadherin expression in ketamine-induced cystitis. Toxicology Reports, 2, 205-209. doi:10.1016/j.toxrep.2014.12.003.

[17] McHale, N. G., Hollywood, M. A., Sergeant, G. P., Shafei, M., Thornbury, K. T., \& Ward, S. M. (2006). Organization and function of ICC in the urinary tract. The Journal of Physiology, 576(3), 689-694. doi:10.1113/jphysiol.2006.116657.

[18] Medical manual. Adenoma and prostate cancer. Available from: http://www.medical-enc.ru/prostata/klinika-idiagnostika-adenomy.shtml.

[19] Okada, S., Kojima, Y., Kubota, Y., Mizuno, K., Sasaki, S., \& Kohri, K. (2010). Attenuation of bladder overactivity in KIT mutant rats. BJU International, 108(2b), E97-E103. doi:10.1111/ j.1464-410x.2010.09870.x.

[20] Overed-Sayer, C., Rapley, L., Mustelin, T., \& Clarke, D.L. (2014). Are mast cells instrumental for fibrotic diseases? Frontiers in Pharmacology, 4(174). doi:10.3389/fphar.2013.00174

[21] Ratne, V. (2015). Mast cell activation syndrome. Transl. Androl. Urol., 4(5), 587-588. doi: 10.3978/j.issn.2223-4683.2015.09.03

[22] Sanders, K. M., Ward, S. M., \& Koh, S. D. (2014). Interstitial Cells: Regulators of Smooth Muscle Function. Physiological 
Reviews, 94(3), 859-907. doi:10.1152/physrev.00037.2013.

[23] Sapoznikov, A. G., \& Dorosevich, A. E. (2000). Histological and microscopical technique: Handbook. Smolensk: SAU. ISBN 5-7977-0003-4.

[24] Smet, P. J., Jonavicius, J., Marshall, V. R., \& Vente, J. D. (1996). Distribution of nitric oxide synthase-immunoreactive nerves and identification of the cellular targets of nitric oxide in guineapig and human urinary bladder by cGMP immunohistochemistry. Neuroscience, 71(2), 337-48.

[25] Studnitskiy, V. B., \& Pelyuh, P. F. (2015). The role of some derivatives of mesenchymal tissue in the formation of periodic activity of the gastrointestinal tract. Siberian Journal of Science, 15, 326-332.

[26] Vahabi, B., McKay, N. G., Lawson, K., \& Sellers, D. J. (2011). The role of c-kit-positive interstitial cells in mediating phasic contractions of bladder strips from streptozotocin-induced diabetic rats. BJU International., 107(9), 1480-1487. doi:10.1111/j.1464-410x.2010.09507.x

[27] Yaglova, N. V., \& Yaglov, V. V. (2012). Biology of mast cell secretion. Clinical and experimental morphology, 4, 4-10.

МОРФОЛОГІЧНИЙ АНАЛІЗ ІНТЕРСТИЦІАЛЬНИХ КЛІТИН КАХАЛЯ І БАЗОФІЛЬНИХ ГРАНУЛОЦИТІВ ПРИ ГІПЕРАКТИВНОМУ СЕЧОВОМУ МІХУРІ ТА СТРЕСОВОМУ НЕТРИМАННІ СЕЧІ В ЕКСПЕРИМЕНТІ ПІД ВПЛИВОМ ФАРМАКОКОРЕКЦІЇ

Яцина О.І., Вернигородський С.В., Костєв Ф.І.

Сучасні уявлення вказують на багатофракторні механізми розвитку гіперактивного сечового міхура (ГАСМ), однак до кінця питання патогенезу ГАСМ залишаються не з'ясованими. Останнім часом поряд з нейрогенною теорією виникнення ГАСМ все більща увага приділяється вивченню морфологічних змін, що виникають в гладких міоцитах детрузора $i$ взаємодії ї 3 екстрацелюлярним матриксом. Тому метою нашого дослідження стало за допомогою гістохімічних та імуногістохімічних методів оцінити розподіл інтерстиціальних клітин Кахаля (ІКК) і базофрільних гранулоцитів (БГ) в структурних елементах стінки сечового міхура при стресовому нетриманні сечі і його гіперактивності до і після лікування мірабегроном, спазмексом, кверцетином і їх комбінації з тестостероном і естрадіолом. На експериментальних моделях ГАСМ і стресового нетримання сечі (CHM) за допомогою гісто- $i$ імуногістохімічного методу виявлено підвищення кількості та функціональної активності БГ, а також ІКК на всіх термінах спостереження при ГАСМ, в той час як при СНМ кількість і функціональна активність БГ були високими тільки після 14 діб експерименту. Після 28 діб спостерігали різке їх зменшення, що свідчило про декомпенсацію і виснаження їх функціональної активності. Кількість ІКК зменшується при СНМ як після 14 діб, так і через 28 діб експерименту. У групі експериментальних тварин, які отримували спазмекс і комбінацію його з гормонами не виявлено достовірної ефективності їх впливу на кількісний і якісний склад БГ та ІКК при ГАСМ і СНМ на 14 добу експерименту, проте в поєднанні з тестостероном виявлено достовірне $(p<0,001)$ зниження експресії БГ і ІКК у м'язовому шару сечового міхура після 14 діб, і недостовірне через 28 діб (p>0,05). При окремому застосуванні мірабегрона і особливо при його комбінації з тестостероном і естрадіолом встановлена позитивна динаміка гістохімічних та імуногістохімічних показників експресії БГ і ІКК. З'ясовано високу ефективність кверцетину в поєднанні з тестостероном і естрадіолом при ГАСМ та СНС, що підтверджується стабілізацією функціональної активності БГ і кількісного складу ІКК.

Ключові слова: гіперактивний сечовий міхур, стресове нетримання сечі, імуногістохімічний аналіз, інтерстиціальні клітини Кахаля, базофрільні гранулоцити, фрармацевтична корекція.

\section{МОРФОЛОГИЧЕСКИЙ АНАЛИЗ ИНТЕРСТИЦИАЛЬНЫХ КЛЕТОК КАХАЛЯ И БАЗОФИЛЬНЫХ ГРАНУЛОЦИТОВ ПРИ ГИПЕРАКТИВНОМ МОЧЕВОМ ПУЗЫРЕ И СТРЕССОВОМ НЕДЕРЖАНИИ МОЧИ В ЭКСПЕРИМЕНТЕ И ПРИ ФАРМАКОКОРРЕКЦИИ}

\section{Яцина А.И., Вернигородский С.В., Костев Ф.И.}

Современные представления указывают на многофракторные механизмы развития гиперактивного мочевого пузыря (ГАМП), однако окончательно вопросы патогенеза ГАПМ остаются не выясненными. Последнее время наряду с нейрогенной теорией возникновения ГАПМ, все большее внимание уделяется изучению морфологических изменений, возникающих в гладких миоцитах мышцы, выталкивающей мочу и взаимодействия их с экстрацеллюлярным матриксом. Поэтому целью нашего исследования стало с помощью гистохимических и иммуногистохимических методов оценить распределение интерстициальных клеток Кахаля (ИКК) и базофильных гранулоцитов (БГ) в структурных элементах стенки мочевого пузыря при стрессовом недержании мочи и его гиперактивности до и после лечения мирабегроном, спазмексом, кверцетином и их комбинации с тестостероном и эстрадиолом. На экспериментальных моделях гиперактивного мочевого пузыря и стрессового недержания мочи (CHM) с помощью гисто- и иммуногистохимического метода обнаружено повышение количества и функциональной активности БГ, а также ИКК на всех сроках наблюдения при ГАМП, в то время как при СНМ количество и функциональная активность БГ были высокими только после 14 суток эксперимента. После 28 суток наблюдали резкое их уменьшение, что свидетельствовало о декомпенсации и истощении их функциональной активности. Количество ИКК снижалась при СНМ как после 14 суток, так и после 28 суток эксперимента. В группе экспериментальных животных, получавших спазмекс и комбинацию его с гормонами, не обнаружено достоверной эффрективности их влияния на количественный и качественный состав БГ и ИКК при ГАМП и СНМ на 14 сутки эксперимента, однако в сочетании с тестостероном отмечено достоверное $(p<0,001)$ снижение экспрессии БГ и ИКК в мышечном слоя мочевого пузыря после 14 суток и недостоверное после 28 суток (p>0,05). При отдельном применении мирабегрона и, особенно, при его комбинации с тестостероном и эстрадиолом установлена положительная динамика гистохимических и иммуногистохимических показателей экспрессии БГ и ИКК. Установлена высокая эфффективность кверцетина в сочетании с тестостероном и эстрадиолом при ГАМП и СНС, что подтверждалось стабилизацией ффункциональной активности БГ и количественного состава ИКК.

Ключевые слова: гиперактивный мочевой пузырь, стрессовое недержание мочи, иммуногистохимический анализ, интерстициальные клетки Кахаля, базофильные гранулоциты, фрармацевтическая коррекция. 